\title{
Encoal Mild Coal Gasification Demonstration Project
}

\author{
Annual Report \\ Octoher 1, 1991 - September 30, 1992
}

Deceniber 1993

Work Performed Under Contract No.: DE-FC21-90MC27339

For

U.S. Department of Energy

Office of Fossil Energy

Morgantown Energy Technology Center

Morgantown, West Virginia

By

Encoal Corporation

A Subsidiary of SMC Mining Company

Gillette, Wyoming 


\section{DISCLAIMER}

This report was prepared as an account of work sponsored by an agency of the United States Government. Neither the United States Government nor any agency thereof, nor any of their employees, makes any warranty, express or implied, or assumes any legal liability or responsibility for the accuracy. completeness, or usefulness of any information, apparatus, product, or process disclosed. or represents that its use would not infringe privately owned rights. Reference herein to any specific commercial product, process, or service by trade name, trademark, manufacturer, or otherwise does not necessarily constitute or imply its endorsement, recommendation, or favoring by the United States Government or any agency thereof. The views and opinions of authors expressed herein do.not necessarily state or reflect those of the United States Government or any agency thereot.

This report has been reproduced directly from the best available copy.

Available to DOE and DOE contractors from the Office of Scientific and Technical Information, P.O. Box 62, Oak Ridge, ' N 37831; prices available from (615) 576-8401.

Available to the public from the U.S. Department of Commerce, Technology Administation, National Technical Information Service, Springfield, VA 22161 , (70)3 487-4650. 


\title{
Encoal Mild Coal Gasification
}

Demonstration Project

\author{
Annual Report \\ October 1, 1991 - September 30, 1992
}

Work Performed Under Contract No.: DE-FC21-90MC27339

\author{
For \\ U.S. Department of Energy \\ Office of Fossil Energy \\ Morgantown Energy Technology Center \\ P.O. Box 880 \\ Morgantown, West Virginia 26507-0880 \\ By \\ Encoal Corporation \\ A Subsidiary of SMC Mining Company \\ P.O. Box 3038 \\ Gillette, Wyoming 82717
}

December 1993 


\section{TABLE OF CONTENTS}

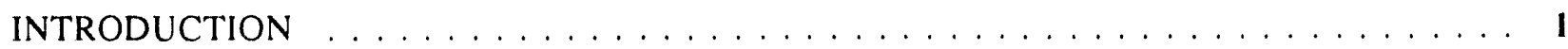

BACKGROUND INFORMATION $\ldots \ldots \ldots \ldots \ldots \ldots \ldots \ldots \ldots \ldots$

PROJECT ORGANIZATION OVERVIEW $\ldots \ldots \ldots \ldots \ldots \ldots \ldots \ldots \ldots \ldots$ I

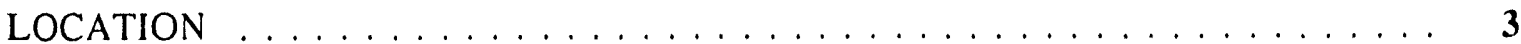

PROCESS CONCEPT $\ldots \ldots \ldots \ldots \ldots \ldots \ldots \ldots \ldots \ldots \ldots \ldots$

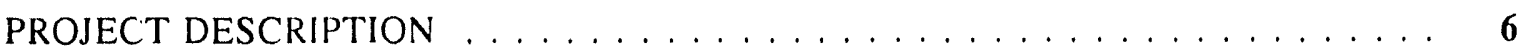

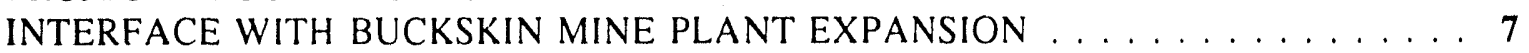

EXECUTIVE SUMMARY FOR QUARTERS 1,2 , AND $3 \ldots \ldots \ldots \ldots \ldots$

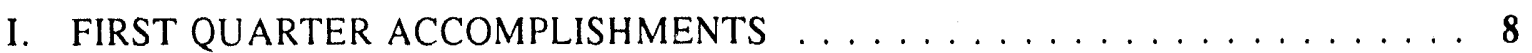

2.0 PHASE II -- CONSTRUCTION AND START-UP $\ldots \ldots \ldots \ldots \ldots .8$

II. SECOND QUARTER ACCOMPLISHMENTS $\ldots \ldots \ldots \ldots \ldots \ldots \ldots$

2.0 PHASE II -. CONSTRUCTION AND START-UP $\ldots \ldots \ldots \ldots \ldots \ldots$

III. THIRD QUARTER ACCOMPLISHMENTS . . . . . . . . . . . 12

2.0 PHASE II -- CONSTRUCTION AND START-UP $\ldots \ldots \ldots \ldots \ldots \ldots$

EXECUTIVE SUMMARY $\ldots$ FOURTH QUARTER $\ldots \ldots \ldots \ldots \ldots \ldots \ldots \ldots . \ldots 14$

PLANNED SCOPE OF WORK $\ldots \ldots \ldots \ldots \ldots \ldots \ldots \ldots \ldots \ldots, 14$

ACCOMPLISHMENTS ....................... 14

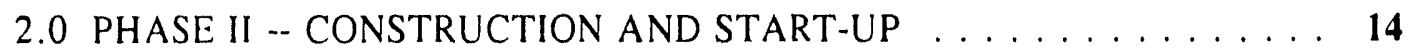

3.0 PHASE III -- OPERATION, DATA COLLECTION, AND REPORTING . . 15

3.1 Operation and Maintenance ................ 15

3.2 Data Collection and Reporting . . . . . . . . . . . . . 16

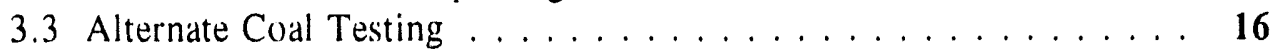

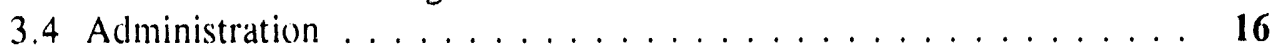

3.5 Equipment Modifications $\ldots \ldots \ldots \ldots \ldots \ldots \ldots \ldots$

TECHNICAL IMPACTS ON SCHEDULE AND MILESTONES $\ldots \ldots \ldots \ldots \ldots \ldots .18$

CONCLUSIONS AND LOOK AHEAD $\ldots \ldots \ldots \ldots \ldots \ldots \ldots \ldots \ldots \ldots$

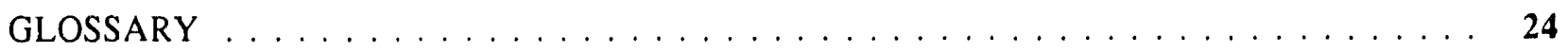




\section{LIST OF TABLES}

TABLE 1: PHASE I AND II MILESTONE LOG $\ldots \ldots \ldots \ldots \ldots \ldots \ldots \ldots$

TABLE 2: PHASE III MILESTONE LOG $\ldots \ldots \ldots \ldots \ldots \ldots \ldots \ldots \ldots$

\section{LIST OF FIGURES}

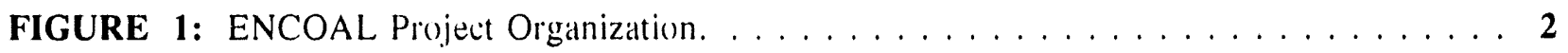

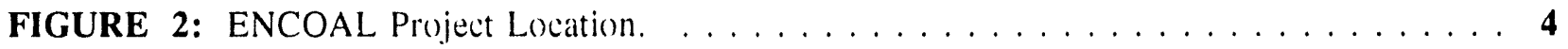

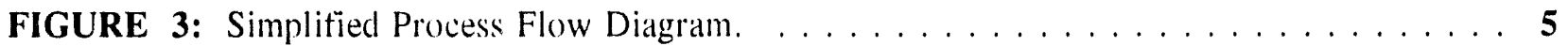

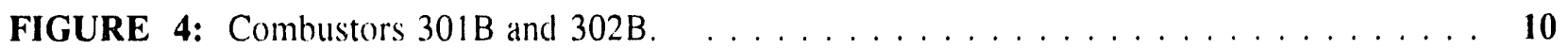

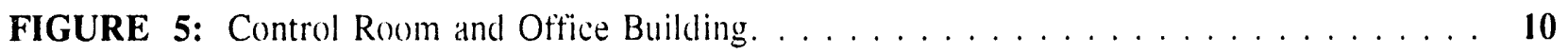

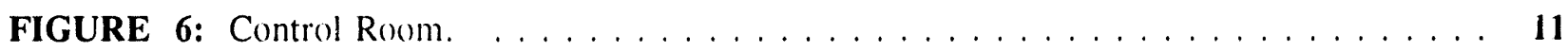

FIGURE 7: Screening Building and Fines Loadout Conveyor. $\ldots \ldots \ldots \ldots \ldots$

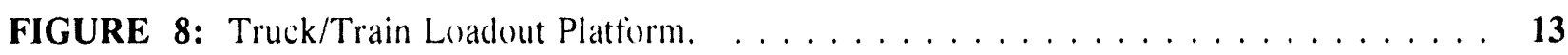

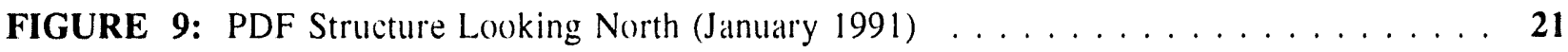

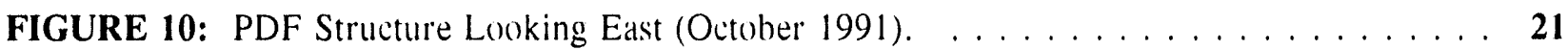

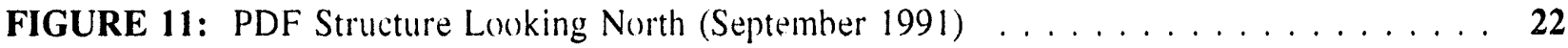

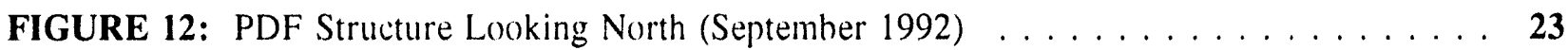




\section{INTRODUCTION}

This document is the combination of the fourth quarter report (July - September 1992) and the 1992 annual report for the ENCOAL project. The following pages include the background and process description for the project, brief summaries of the accomplishments for the first three quarters, and a detailed fourth quarter report. Its purpose is to convey the accomplishments and current progress of the project.

\section{BACKGROUND INFORMATION}

ENCOAL Corporation, a wholly-owned subsidiary of Shell Mining Company, has completed the construction of a mild gasification demonstration plant at Triton Coal Company's Buckskin Mine near Gillette, Wyoming. The process, using Liquids From Coal (LFC) technology developed by Shell and SGI International, utilizes low-sulfur Powder River Basin coal to produce two new fuels, Process Derived Fuel (PDF) and Coal Derived Liquids (CDL). The products, as alternative fuels sources, are expected to significantly reduce current sulfur emissions at industrial and utility boiler sites throughout the nation, thereby reducing pollutants causing acid rain.

ENCOAL submitted an application to the U.S. Department of Energy (DOE) in August, 1989, soliciting joint funding of the project in the third round of the Clean Coal Technology Program. The project was selected by DOE in December, 1989 and the Cooperative Agreement approved in September, 1990.

\section{PROJECT ORGANIZATION OVERVIEW}

ENCOAL has agreed to execute the ENCOAL Mild Gasification Project. ENCOAL is the signatory to the Cooperative Agreement and will continue to be owner, manager and operator of the demonstration plant. ENCOAL is responsible for all aspects of the project, including design, permitting, construction, operation, data collection and reporting. ENCOAL managed the design and construction of the project through a project manager, who was assisted by a team of technical and managerial personnel. The engineering, procurement and construction of the plant was contracted to The M. W. Kellogg Company. Coal that is processed during plant operation is purchased from the site host, Triton Coal Company. Triton also provides access to the site, associated facilities and infrastructure vital to the project and administrative services. Equity funding, administrative services, and product marketing services for the project are provided by Shell Mining Company. Additional technical development support is provided by TEK-KOL, which also has the primary responsibility for commercialization. All assets are assigned to ENCOAL, while all technology rights are held by TEK-KOL and licensed to ENCOAL. (Figure 1 depicts the organization of the project team.) 


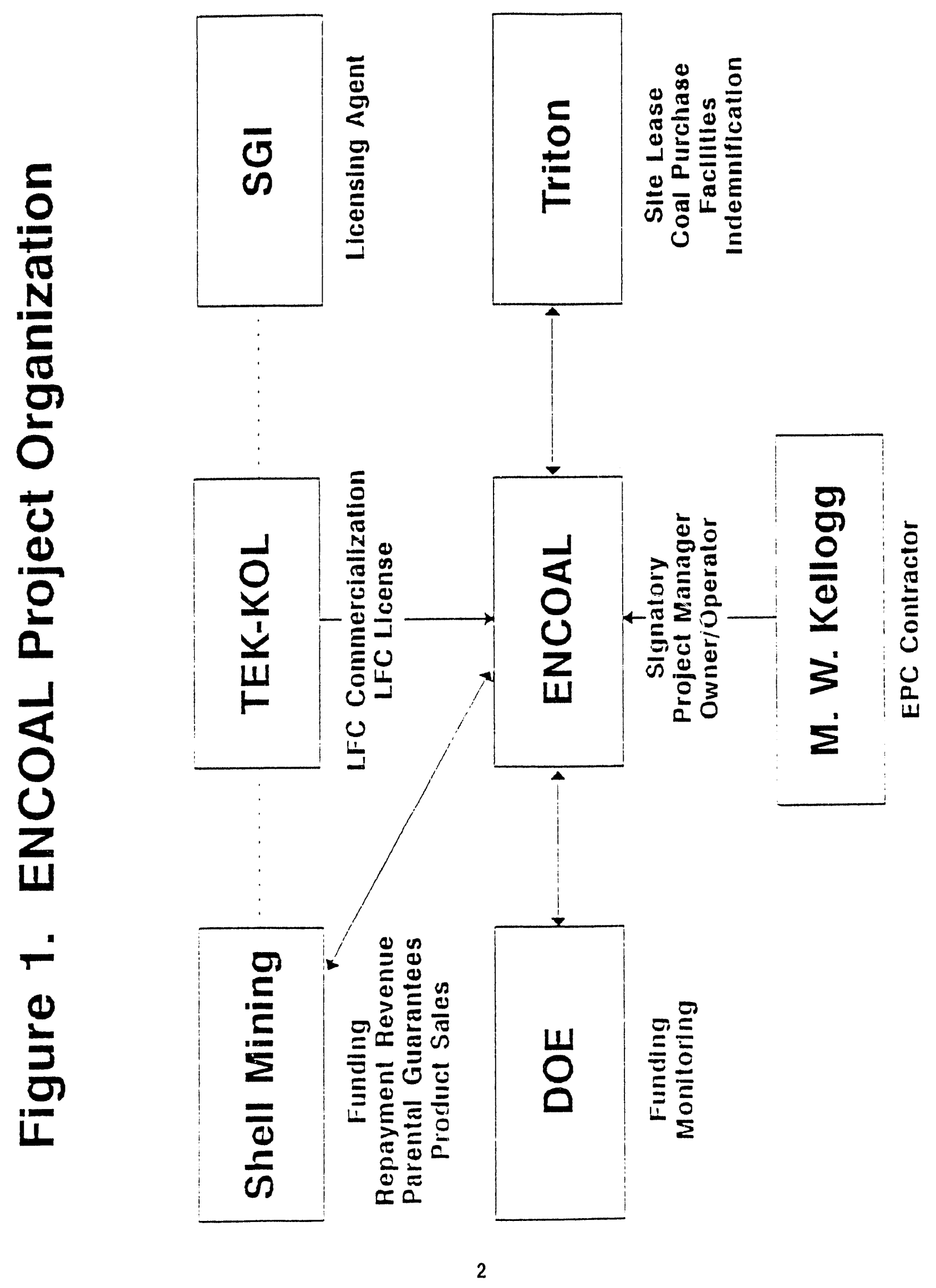




\section{LOCATION}

The demonstration plant site is located in Campbell County, Wyoming, approximately ten miles north of the county seat of Gillette (Figure 2). The site is within the Triton Coal Company's, (a wholly owned subsidiary of Shell Mining Company), Buckskin Mine boundary, proximal to the mine's rail transportation loop. Active coal mining and reclamation activities surround the demonstration plant site.

\section{PROCESS CONCEPT}

The LFC technology uses a mild pyrolysis or mild gasification process which involves heating the coal under carefully controlled conditions. The process causes chemical changes in the feed coal in contrast to conventional drying, which leads only to physical changes. Wet subbituminous coal contains considerable water, and conventional drying processes physically remove some of this moisture, causing the heating value to increase. The deeper the coal is physically dried, the higher the heating value and the more the pore structure permanently collapses, preventing resorption of moisture. However, deeply dried Powder River Basin coals exhibit significant stability problems when dried by conventional thermal processes. The LFC process overcomes these stability problems by thermally altering the solid to create PDF and CDL. The PDF is a stable low sulfur, high BTU fuel similar in composition and handling properties to bituminous coal. CDL is a heavy, low sulfur liquid fuel similar in properties to a Number 6 fuel oil.

Briefly, in the LFC technology, coal is first deeply dried to remove water physically. The temperature is further raised in a second stage which results in decomposition reactions that form the new products. This chemical decomposition (mild gasification) creates gases by cracking reactions from the feed coal. The chemically altered solids are cooled aild further processed to make PDF. The gases are cooled, condensing liquids as CDL, and the residual gases are burned in the process for heat.

Figure 3 is a simplified flow diagram of the ENCOAL process. Run-of-mine coal is supplied to the demonstration plant from existing Buckskin Mine storage silos. The coal is transferred periodically to a new 3000-ton storage silo. Coal from this silo is sized by crushing and screening to 2" X 1/8", continuously fed (1000 ton/day) onto a conveyor belt by a vibrating feeder and lifted about 195 feet to the top of the plant building (the entry point to the dryer on Figure 3).

The coal is then fed into a rotary grate dryer where it is heated by a hot gas stream. The residence time and temperature of the inlet gas have been selected to reduce the moisture content of the coal without initiating pyrolysis or chemical changes. The solid bulk temperature is controlled so that no significant amounts of methane, carbon monoxide, or carbon dioxide are released from the coal. 
Figure 2. ENCOAL Project Location

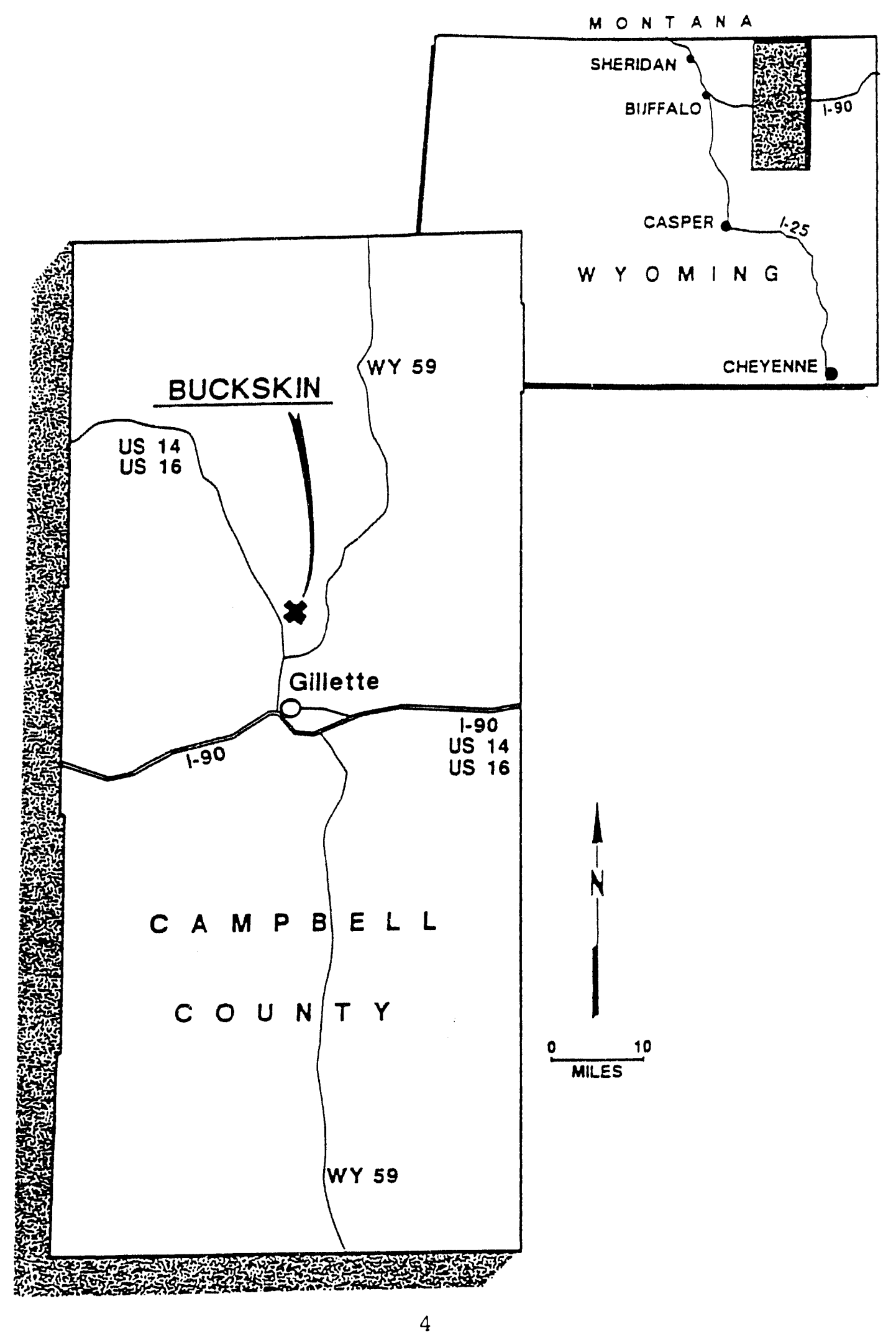




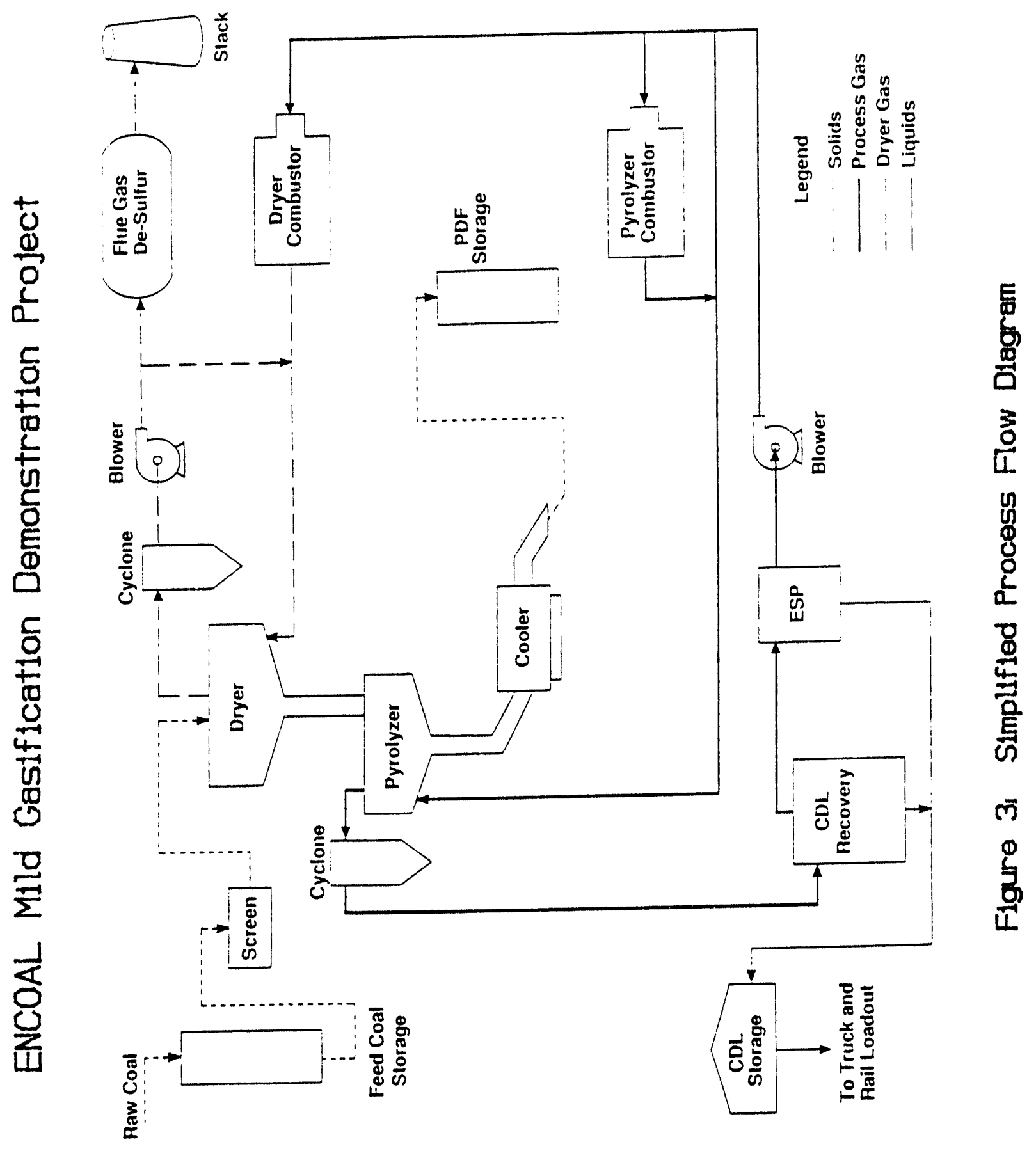


The solids then report to the pyrolyzer where the temperature is further raised to about 1000 " $F$ on another rotary grate by a hot recycled gas stream. The rate of heating of the solid and its residence time are carefully controlled as these parameters affect the properties of both products. During processing in the pyrolyzer, all remaining free water is removed and the chemical reactions occur. After leaving the pyrolyzer, the solids are quickly cooled to stop the pyrolysis reactions.

The cooled solids are transferred to a surge bin. Since the solids will be dusty, having no surface moisture, they require dust suppression. A very effective dust suppressant patented by Shell Mining Company, called MK, will be added to the solid product as it leaves the surge bin. The resulting new fuel form is now called PDF. It is transferred to storage silos where it is held for shipment by rail through existing Buckskin loadout facilities.

In the liquids recovery section of the plant, the pyrolysis gas stream or make gas leaving the pyrolyzer is cooled in a quench tower to stop any additional pyrolysis reactions and to condense the desired hydrocarbons. The gas temperature is kept above the dew point of the water so that only CDL is condensed. This step prevents the formation of water in the process and the resulting separation and disposal problems.

Most of the residual gas from the condensation unit is recycled to the pyrolyzer by a blower. Some of this gas is burned in the pyrolyzer combustor and blended with the recycled gas which provides heat for the pyrolyzer.

The remaining gas is burned in the dryer combustor which converts all sulfur compounds to sulfur oxides. Nitrogen oxide emissions are controlled by appropriate design of the combustor, based on evaluation of $\mathrm{NO}_{x}$ control technologies for low BTU gases. The hot flue gas is blended with the recycle gas from the dryer to provide heat and gas flow necessary for drying. The offgas from the dryer is treated first in a wet scrubber followed by a horizontal scrubber, both using a water-based sodium carbonate solution. The wet gas scrubber recovers fine particulates that escape the dryer cyclone and the horizontal scrubber removes most of the sulfur oxides from the flue gas. The spent solution discharges into a clay lined pond for evaporation.

\section{PROJECT DESCRIPTION}

The ENCOAL project involves the design, construction and operation of a 1000 ton per day mild coal gasification demonstration plant and all required support facilities. A significant reduction in work scope and cost is being realized on the project due to the existence of the host Buckskin Mine. Coal storage and handling facilities, rail loadout, access roads, utilities, office, warehouse and shop facilities are all present at the mine site and thus reduce the need for new facilities for the ENCOAL project. Operations staff, supervision, administrative services and site security are being provided under contract with Triton Coal Company. The balance of the project requirements are being provided by ENCOAL and its subcontractors. 
The project is divided into three phases listed as follows:

Phase I - Design and Permitting

Phase II -- Construction and Start-up

Phase III -- Operation. Data Collection, and Reporting

Two budget periods encompass the work, the first covering Phases I and II and the second covering Phase III. A typical Work Breakdown Structure has been developed for the project.

Engineering, procurement and construction management (EPC) for the project was handled by The M.W. Kellogg Company. Kellogg's scope of work included home offied design, project coordination, field construction supervision, scheduling, project controls, procurement and project management.

ENCOAL and Triton are handling the operations planning, training, maintenance planning, staffing, plant commissioning and start-up, data gathering and plant operation. Other than the actual plant operation, many of these activities took place in Phase II. Preparation of written plans and manuals was also a part of these activities. All permitting requirements were handled by ENCOAL, and field engineering and construction support was handled by ENCOAL's technical team.

\section{INTERFACE WITH BUCKSKIN MINE PLANT EXPANSION}

The Buckskin Mine plant expansion project commenced construction in 1990 adjacent to the ENCOAL project site. The expansion will allow the mine to eventually increase coal production to 20 million tons per year and involves the construction of three new 12,000 ton silos, automated batch loadout facility, transfer tower, in-pit hopper and associated conveyors.

The decisions and approvals of the Buckskin Mine project were made independent of and subsequent to ENCOAL's Cooperative Agreement with the DOE. The interface and proximity of the ENCOAL project and the plant expansion provided optimization oppostunities for ENCOAL, but also required changes in some instances from ENCOAL's original proposal and Project Management Plan. Examples were changes in grade elevations, moving conveyor supports, use of existing MCC buildings, and moving temporary construction facilities. 


\section{EXECUTIVE SUMMARY FOR QUARTERS 1, 2, AND 3}

During the first three reporting periods, ENCOAL made great strides in keeping ahead of the DOE baseline schedule. Construction of the project was completed and both electrical and mechanical maintenance contracts were awarded. Operator training sessions were completed and all systems were commissioned and fully integrated as one unit. ENCOAL submitted its Continuation Application to the DOE on May 17, 1992 for moving on to Phase III of the project. The Pre-Manufacture Notice for PDF was granted by the EPA, and ENCOAL's Environmental Monitoring Plan was approved by the DOE. Initial plant start-up was achieved and the project was moving toward full start-up and testing operations.

\section{FIRST QUARTER ACCOMPLISHMENTS - Octobe:" : :irough December 1991}

\subsection{PHASE II -- CONSTRUCTION AND START-UP}

The demobilization of the M.W. Kellogg engineering task force in July 1991, transferred responsibility for all remaining engineering items to ENCOAL. As a result, the significant amount of field engineering design became a high priority during the quarter. Construction of the project dominated the activities of both the ENCOAL and KCI field groups. Emphasis was placed on expediting late vendor information and equipment. A field revised version of the P\&ID's was issued in December incorporating all available vendor information.

Erection of the PDF structure, equipment, and above ground piping proceeded well. Steel work progressed to the 162 foot level and lights were energized on the first two levels of the building. An insulation subcontract was awarded, and a contract for ENCOAL's natural gas service was signed and the necessary rightof-way and state permits were obtained.

The Pre-Manufacturing Notice (PMN) for the PDF was submitted to the EPA in December. Drafts of the MSDS for the PDF and CDL were made and underwent an internal review prior to submittal.

Winterization of the project was a high priority with the abrupt arrival of sub-zero winter temperatures in October. Siding for the PDF structure was obtained and propane heating was provided in several of the off-site buildings. Steps were also taken to properly freeze protect and cure refractory material that was already applied. 
Several meetings were held in the month of November discussing the start-up, shut-down, and interlocking procedures. The purpose of these meetings was to identify the sequencing needed for programming the plant PLC, and thus prepare for commissioning. A draft of the preventative maintenance manual was issued, and drafts of the operations and training manuals were either completed or nearly completed by the end of the period. Testing and chemical analysis plans were organized and SGI International completed a preliminary data acquisition procedure for obtaining the necessary information from product samples.

\section{SECOND QUARTER ACCOMPLISHMENTS - January through March 1992}

\subsection{PHASE II -- CONSTRUCTION AND START-UP}

Construction activities were the primary focus for both the ENCOAL and KCI field groups during the quarter. The Operations team concentrated on the operator training classes which began on February 24, 1992. The classes were well received, and many commissioning activities were accomplished during the afternoon "hands-on" sessions. Commissioning and testing plans were also a priority as the project continued to make the transition from construction to operation.

Construction of the PDF structure and equipment progressed well. Structural steel for the PDF Building was completed and turned over, and the screening building structural steel was essentially completed with only punch list items remaining. Both the discharge stack and the emergency vent were raised into place, and all Salem Furnace equipment was received and installed with only minor rework required.

Installation of refractory material in the combustors, dryer cyclone, and large diameter duct was completed with the favorable winter weather conditions experienced during this quarter. With the completion of the dryer cyclone, all refractory material was in place. The combustors $301 \mathrm{~B}$ and $302 \mathrm{~B}$ were utilized for the final dry-out and curing of the material (See Figure 4 -- Combustors $301 B$ and 302B).

The natural gas company completed installation of the main supply pipeline and the supply lines to the control room and PDF structure were commissioned and charged with gas (See Figures 5 and 6 -- Control Room and Office Building). The off-sites above ground piping contract work was also completed in February with the exception of the train load-out platform. The erection of the platform was rescheduled for April due to delivery delays. 


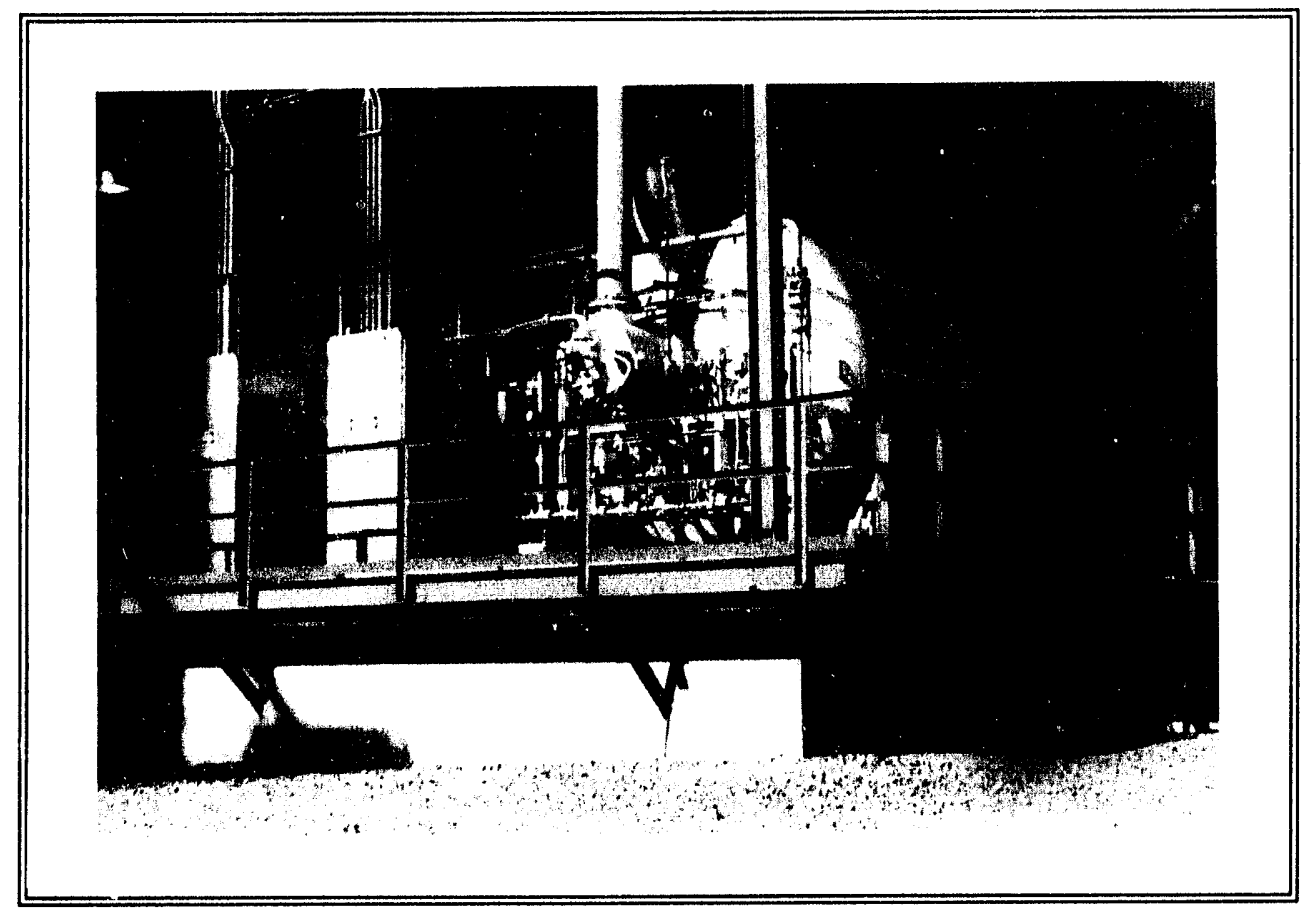

FIGURE 4: Combustors 301B and 302B.

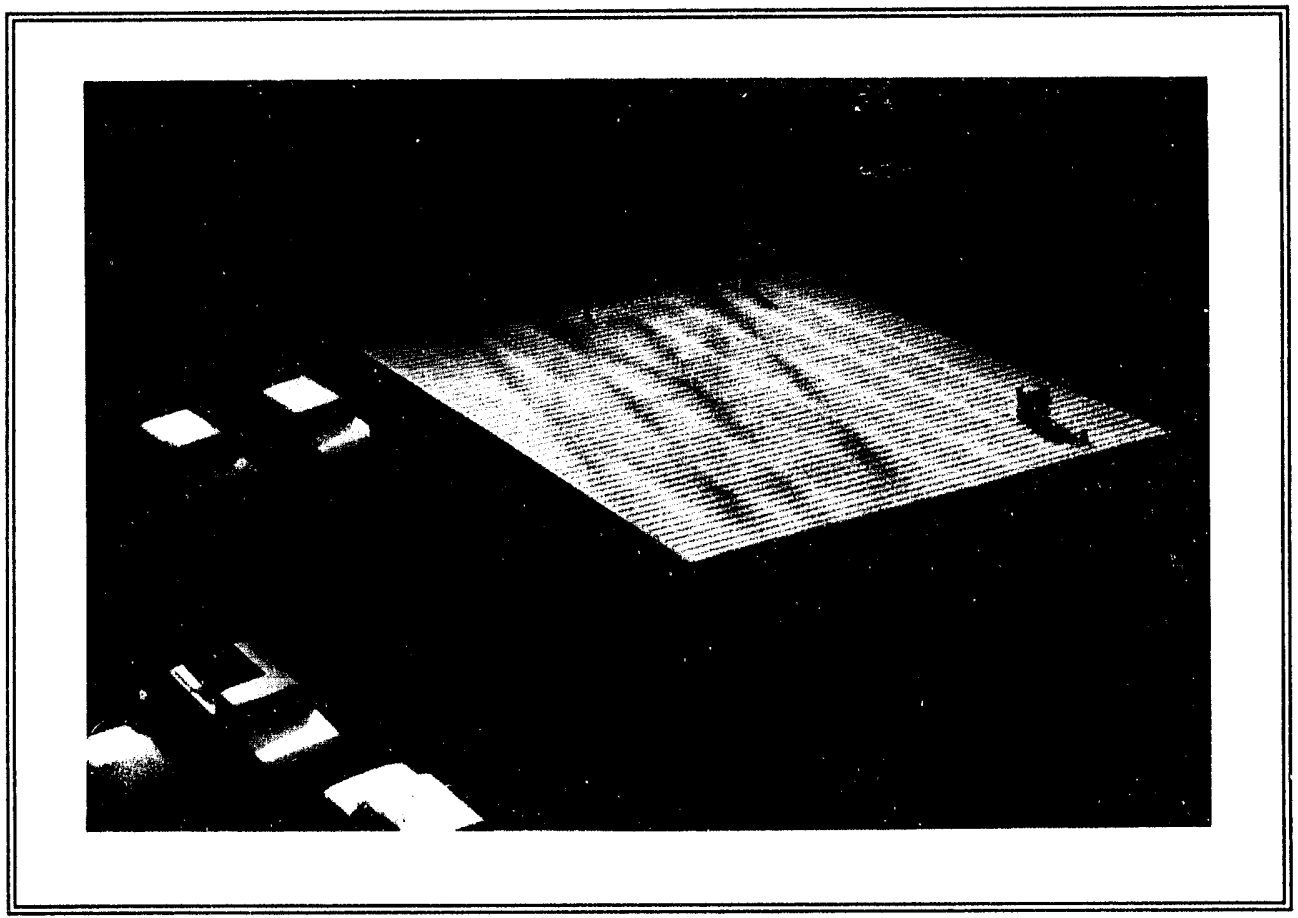

FIGURE 5: Control Room and Office Building. 


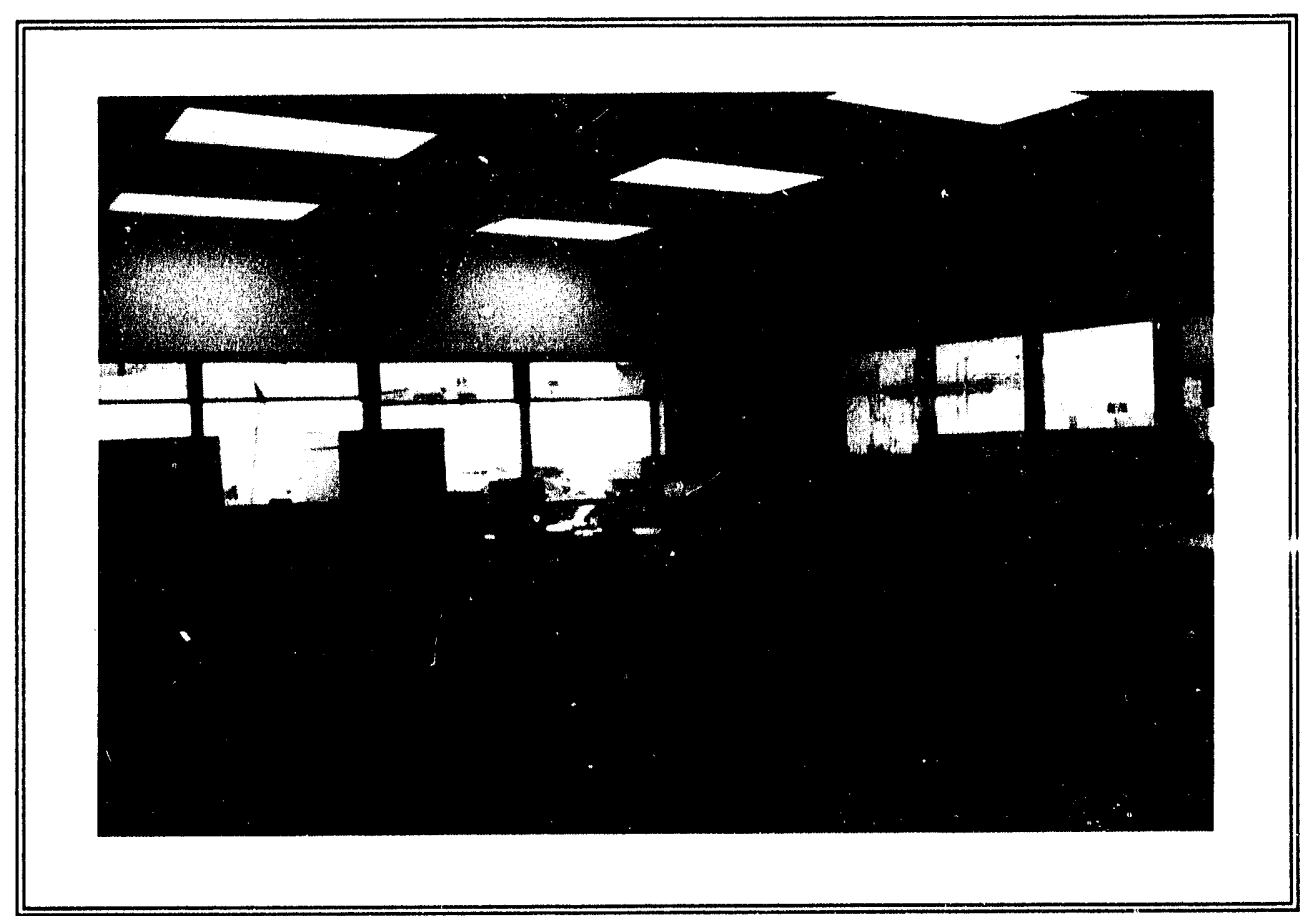

FIGURE 6: Control Room.

A pneumatic test on the large bore piping was initiated on March 21. The results of this test indicated that several major equipment items required considerable rework in order to be adequately sealed. The pyrolyzer and dryer shells had to be seal welded at the interior joints to make them air tight. The large blowers $101 \mathrm{~J}$ and $301 \mathrm{~J}$ needed to be dismantled and the porous gasket material supplied by the manufacturer replaced with impermeable material.

Several meetings were held during the quarter discussing the commissioning and testing procedures. The purpose of these meetings was to develop a sequential work schedule to coordinate all commissioning activities. A meeting was also held to discuss the noise and ventilation surveys of the plant. Topics of discussion centered on the potential problems, methods of solutions, and scheduling of the surveys themselves.

A meeting was held with the WDEQ in Cheyenne, WY to discuss the permit stipulations for continuous $\mathrm{SO}_{2}$ stack monitoring. An agreement was reached on the quality control procedures, reporting requirements, conditions for monitoring, and the specifications for the monitoring equipment. A permit was issued on January 21, 1992 based on these conditions.

Approval of the Pre-Manufacture Notice (PMN) for PDF was granted by the Environmental Protection Agency. The document underwent the standard 90 day review without receiving any comments. 
The coal purchase agreement with Triton Coal for the supply of raw coal for the plant was updated. Modifications were required to reflect the method of measurement of coal that the plant will use, and to allow for the purchase of sized coal from Triton.

\section{THIRD QUARTER ACCOMPLISHMENTS - April through June 1992}

\subsection{PHASE II -- CONSTRUCTION AND START-UP}

Construction of the PDF structure and equipment was entirely completed during the quarter. Structural steel for the screening building was turned over to ENCOAL, and installation of the siding for the PDF structure was completed on all sides (See Figure 7 -- Screening Building and Fines Loadout Conveyor). The CDL truck/train load-out platform was erected and the CDL meter and retractable arm were set into place. With the erection of the platform, construction of the above ground piping was entirely completed (See Figure 8 -- Truck/Train Loadout Platform). The electrical and insulation subcontract work were also concluded. $\mathrm{KCI}$ and their subcontractors demobilized in May and all construction personnel were off site by the end of June.

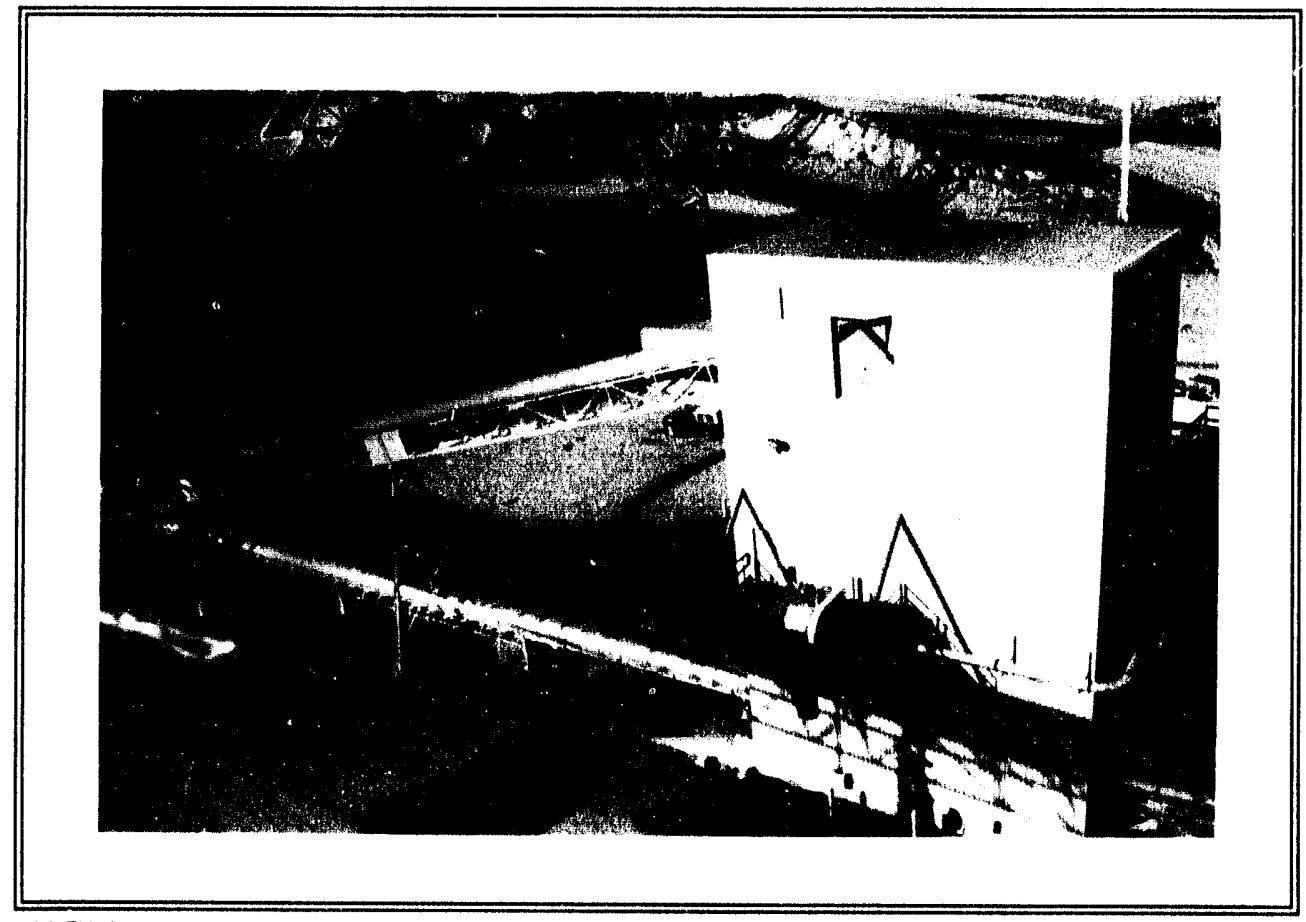

FIGURE 7: Screening Building and Fines Loadout Conveyor. 


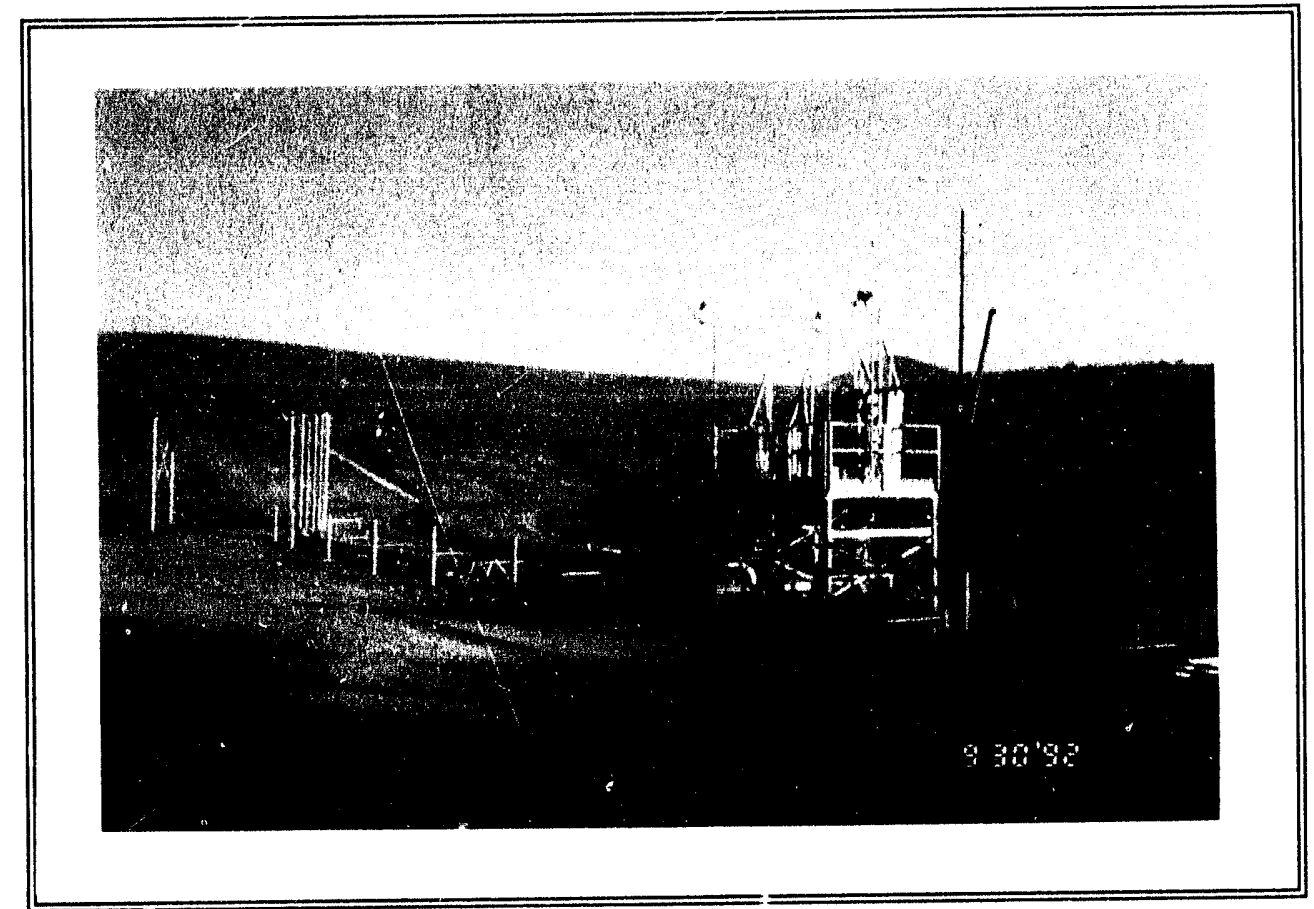

FIGURE 8: Truck/Train Loadout Platform.

The project successfully completed the transition from construction to plant operation. On May 17, 1992, ENCOAL submitted its Continuation Application to the DOE for moving on to Phase III of the project. Commissioning activities were concluded, and all statement of work items were completed for Phases I and II. On June 17, 1992 all systems became fully integrated and the ENCOAL Mild Gasification Plant became fully operational. The plant completed its first 24 hour continuous run making both PDF and CDL.

The Operations Team completed commissioning activities and initial plant start-up during the quarter. Several cold coal runs were made to test the Salem equipment and Renneburg cooler under loaded conditions. Both combustors were ramped up to hot stand-by temperatures and final loop checks were completed.

A formal permit for the plant boiler emissions was received from the WDEQ. As expected, a standard permit was issued with no special conditions. Commissioning plans proceeded as scheduled. 
Several pneumatic tests were conducted on the large bore piping. The pneumatic testing identified a design problem with the explosion doors. The original design released at 5 inches of water, which was approximately one sixth of the desired release pressure. ENCOAL worked in conjunction with the door manufacturer to design a new latch for the doors. All five doors were modified with the new design to hold a seal under the design pressure. Other minor leaks found in various flanged connections were either seal welded or had new gaskets installed depending upon pipe size, location, and availability of gasket material.

ENCOAL awarded an electrical and instrumentation contract to a small, local firm during the month of April for commissioning and other electrical work. A mechanical maintenance contracı was also awarded earlier in March to aid in accomplishing commissioning operations and other mechanical work. Both contracts provided excellent assistance for plant commissioning and start-up activities.

\section{EXECUTIVE SUMMARY -- FOURTH QUARTER - July through September 1992}

Start-up, operation and shut-down of the plant dominated the activities of the ENCOAL operations team. Plant modifications and run support occupied the technical staff. Several plant tests were achieved. Results of the tests were favorable, and the plant achieved its first continuous one week long run in September. Both PDF and CDL were produced; the first shipment of CDL is planned for October 1992. ENCOAL received approval on its Continuation Application to the DOE and the plant was operating under Phase III by the end of the quarter.

\section{PLANNED SCOPE OF WORK}

Operation, maintenance, and testing activities were to be the primary focus of the plant operations. Several extended plant tests were to be run and ENCOAL was to be operating under Phase III by the end of the quarter. Modifications due to plant testing were to be expected and an updated Project Management Plan was to be submitted to the DOE. The Environmental Monitoring Plan was to be implemented when the plant operation became stable and continuous.

\section{ACCOMPLISHMENTS}

\subsection{PHASE II -- CONSTRUCTION AND START-UP}

Construction and start-up of the Mild Coal Gasification plant, off-sites facilities, and utilities was completed during the first two weeks of the quarter. ENCOAL received approval of the Continuation Application and was operating under Phase III activities by mid-July 1992. Some modifications to the PDF plant and equipment were identified and carried over into Phase III. They are described in section 3.4 below. 


\subsection{PHASE III -- OPERATION, DATA COLLECTION, AND REPORTING}

The Operations Team concentrated on implementing design changes and on plant operation activities during the quarter. Several plant tests were initiated and results of the tests were favorable. Mechanical failures and plant modifications that resulted from plant testing have delayed continuous operation, but good progress was made in both the plant testing and in initial operations activities. The plant achieved its first continuous one week long run in September, and both PDF and CDL were produced.

\subsection{Operation and Maintenance}

Initial plant operations activities continued through the fourth quarter as the various plant tests were implemented and modifications to equipment and systems were made. Nine plant runs were accomplished including two cold solids throughput tests conducted to check the loading of the dryer, pyrolyzer, and rotary cooler. The majority of the plant runs were limited to 48 hours or less due to mechanical problems, equipment modifications, and system de-bugging. One run in September, however, did extend for a one week period followed by a planned normal plant shut-down. Preliminary analysis of the PDF indicated that the heating value of the feed coal was upgraded from $8,400 \mathrm{BTU} / \mathrm{lb}$ to 12,400 BTU/lb. By the end of September, approximately 50,000 gallons of CDL were in storage. The CDL produced was slightly higher in solids and water content than specification number 6 fuel oil, so will be shipped as off-spec product. ENCOAL is presently working with several prospective customers for a projected shipment of the CDL in October.

Two problems with the ESP's were encountered during plant start-up. Full electric potential could not be achieved in two out of the three units. One unit had a bad stress cone on the power-feed cable while the second unit was found to have a cracked insulator. The cable was repaired and a new insulator was installed and full electric potential was restored. Inspection ports were installed on all of the insulator canisters for future equipment maintenance purposes.

A vibration problem within the screening building was also identified during the commissioning activities. Structural vibration measurements were performed on the platform surrounding the vibrating coal screen, and results of these measurements indicate that portions of the platform are being subjected to moderate vibration stresses that should be dampened. Several methods for lessening the vibration in these areas were reviewed and it was decided to install a concrete flowr around the coal screen. Work on installing the floor was initiated and is expected to be complete by mid October. 
Other operations activity included the issuance of bids for vessel insulation, winterization, and concrete work near the PDF silo. These projects are necessary to ensure proper plant performance through the winter months. Work continued on both the mechanical and electrical maintenance contracts. Repairs and design changes were the primary focus, with both contractors aiding in the installation of a new high pressure cooling water system, combustor control valves, and additional plant lighting.

\subsection{Data Collection and Reporting}

Monthly, Quarterly Technical Progress, and Quarterly Environmental Monitoring reports are all now routinely being submitted. The draft Final Design report has been submitted to the DOE for review. The computerized data acquisition systems are also in operation.

\subsection{Alternate Coal Testing}

There was no planned activity in this area during this period.

\subsection{Administration}

The submittal of an Updated Project Management Plan for Phase III activities was delayed due to the pending sale of Shell Mining Company. The PMP is expected to be submitted to the DOE after the new organization is established and any necessary revisions to ENCOAL's policies and procedures are completed.

Accounts payable, accounts receivable, purchasing, payroll, and general accounting support is now being completely handled by Triton under the services agreement since $\mathrm{M}$. W. Kellogg has demobilized. Legal services, human resources, and other administration support continues to be provided by Shell Mining.

\subsection{Equipment Modifications}

A problem with the pyrolyzer rabbles was encountered during initial plant testing in July. The design of the rabble supports in both the dryer and pyrolyzer was found to limit the level of the coal beds to approximately $75 \%$ of design depth. The support posts would not allow coal to flow freely between them, and would therefore furrow the coal into the sand seals if the coal bed got too deep. A new design for the support posts was suggested by the manufacturer and was successful in freeing the coal flow between the rabble supports. Cold coal tests indicated that ful: design coal bed levels are now attainable. 
Excessive amounts of coal dust at the PDF S-belt transfer points was also a concern during initial plant operation, particularly in the start-up and shut-down sequences. These amounts of dust were not expected and became a safety concern due to the danger of a dust explosion. Temporary precautions were taken to alleviate the problem when the plant was operating, however additional dust scrubbers were necessary for a permanent solution. Small, readily available scrubbers were temporarily installed to scrub the various transfer points on the PDF S-belt, Gamma-metric belt, and the PDF silo. Permanent scrubbers will be installed in December due to a three month lead time for design and fabrication.

A problem with the cooling water system was identified during commissioning activities. The system was not developing the proper flow rate due to plugging of the filters with algae. The problem was overcome by changing the size of the filter mesh from 75 microns to 1/32". A chlorination system was also installed to kill the bacteria in the system. The Wyoming Department of Water Quality was contacted and approval was granted to begin chlorination. The capacity of the cooling water booster pump was also identified as a concern. A review of the high pressure water system revealed that a larger booster pump was necessary due to design changes in the system which added to the water requirements. A new pump and piping system was installed which greatly increased the operability of the plant.

Control of the combustors was found to be difficult during start-up. The combination of oxygen excursions in the dryer loop and oscillation of the air to fuel ratios plagued the operation. In particular, the transition from secondary air to primary air in the combustor ramping sequence was not smooth. The original design primary air control valves do not regulate the air flows well under low flow conditions. Once the combustors were ramped past the transition point, the air control would improve, but the fuel to air ratios would fluctuate. An 8" control valve was added to both the dryer and pyrolyzer combustor primary air intakes and much improved the stability of the combustor air flows. Programming changes were also made to both combustors that allowed the natural gas flow to follow the combustion air flow rates. The change was necessary to dampen the oscillations and prevent oxygen excursions due to improper air to fuel ratios. Both changes were implemented during the quarter and were successfully tested during subsequent plant tests.

The $101 \mathrm{~J}$ blower seals caused a gas leak during plant testing. The original teflon seals supplied by the blower manufacturer were worn away by shaft rotation and allowed process gases to escape into an area around the blower. A new longer life seal, which utilizes a nitrogen purge dual carbon gland, was designed and installed by John Crane, INC. The seal is similar to a proven John Crane seal already in service in the plant. The seals were tested during a short September $27^{\text {th }}-28^{\text {th }}$ plant run, and were found to adequately seal the blower shaft. 


\section{TECHNICAL IMPAC'TS ON SCHEDULE AND MILESTONES}

Numerous equipment and process modifications have been made or have been identified from the plant operations thus far. The major impact of these technical challenges has been on ENCOAL's preferred schedule for delivery of PDF for test burns. There have been no significant impacts on the overall project schedule or milestones. Changes were anticipated in the budget, so no adjustments to the cost baseline are expected at this time. No technical barriers have been identified at this point.

\section{CONCLUSIONS AND LOOK AHEAD}

The project completed construction and start-up during the quarter, ahead of the DOE baseline schedule. Several plant tests were achieved and the plant ran continuously for one week in September. All statement of work items were completed for Phase 1 and Phase II project activities except for additional equipment modifications which will continue well into Phase III. (See Table 1: Phase I \& II Milestone Log). The project received approval from DOE on its Continurtion Application to move to Phase III in July 1992, and an updated milestone log for Phase III activities was produced (See Table 2: Phase III Milestone Log). ENCOAL's Environmental Monitoring Plan was put into effect for plant operation. Both PDF and CDL $w$ were produced during the various plant tests, and approximately 50,000 gallons of CDL were in storage by the end of September. (See Figures 9 through 12 for a Pictorial Progress View of the PDF Structure.)

The next quarter activities will include further plant testing and operation. Necessary plant modification work should continue and engineering activities will continue to support this effort. The updated Project Management Plan for Phase III should be drafted, and the first shipment of CDL is planned. 
ENCOAL Mild Gasification Demonstration Project PHASE I \& II MILESTONE LOG

Table 1

\begin{tabular}{|c|c|c|c|c|}
\hline ID. No & Description & $\begin{array}{c}\text { Planned } \\
\text { Completion } \\
\text { Date }\end{array}$ & $\begin{array}{c}\text { Actual } \\
\text { Completion } \\
\text { Date }\end{array}$ & Comments \\
\hline 1 & Mobilize Team/Subcontractors & 17-Sep-90 & 17-Sep-90 & \\
\hline 2 & Complete NEPA & 01-Nov-90 & $01-$ Oct-90 & \\
\hline 3 & Project Management Plan & 01-Dec-90 & 31-Dec-90 & \\
\hline 4 & Design Review - $60 \%$ & 14-Dec-90 & 13-Dec-90 & \\
\hline 5 & Conduct $90 \%$ Design Review & 15-May-91 & 22-May-91 & \\
\hline 6 & Begin Plant Erection & 15-May-91 & 11-Mar-91 & \\
\hline 7 & Complete Engineering & 15-Jul-91 & $15-J u l-91$ & \\
\hline 8 & Complete Plant Construction & 31-May-92 & 31-May-92 & \\
\hline 9 & $\begin{array}{c}\text { Environmental Monitori.ıg } \\
\text { Plan } \\
\end{array}$ & 14-Nov-90 & 31-Oct-90 & \\
\hline 10 & Construction Review - $20 \%$ & 16-May-91 & 23-May-91 & \\
\hline 11 & Design Completion Report & 16-Sep-91 & 17-May-92 & $\begin{array}{c}\text { Draft } \\
\text { Submitted } \\
\end{array}$ \\
\hline 12 & Construction Review & 16-Dec-91 & 7-Apr-92 & \\
\hline 13 & Construction Report & 16-Jul-92 & 7-May-92 & \\
\hline 14 & Complete Commissioning & 16-Sep-92 & 17-June-92 & \\
\hline
\end{tabular}


ENCOAL Mild Gasification Demonstration Project

PHASE III MILESTONE LOG

Table 2

\begin{tabular}{|c|c|c|c|c|}
\hline ID. No & Description & $\begin{array}{c}\text { Planned } \\
\text { Completion } \\
\text { Date }\end{array}$ & $\begin{array}{c}\text { Actual } \\
\text { Completion } \\
\text { Date }\end{array}$ & Comments \\
\hline 1 & $\begin{array}{c}\text { First Shipment } \\
\text { of CDL }\end{array}$ & $31-$ Oct-92 & & \\
\hline 2 & $\begin{array}{c}\text { Updated Project } \\
\text { Management Plan }\end{array}$ & $30-$ Dec-92 & & \\
\hline 3 & $\begin{array}{c}\text { First Unit } \\
\text { Train of PDF }\end{array}$ & $31-$ May-93 & & \\
\hline 4 & Plant Performance Tests & 15-June-93 & & \\
\hline 5 & Operations Review - 50\% & 16-Aug-93 & & \\
\hline 6 & $\begin{array}{c}\text { Technical Performance and } \\
\text { Economic Evaluation Report }\end{array}$ & 1-July-94 & & \\
\hline 7 & Operations Review - 100\% & 24-Sept-94 & & \\
\hline 8 & Alternate Coal Testing & 17-Sept-94 & & \\
\hline \hline
\end{tabular}




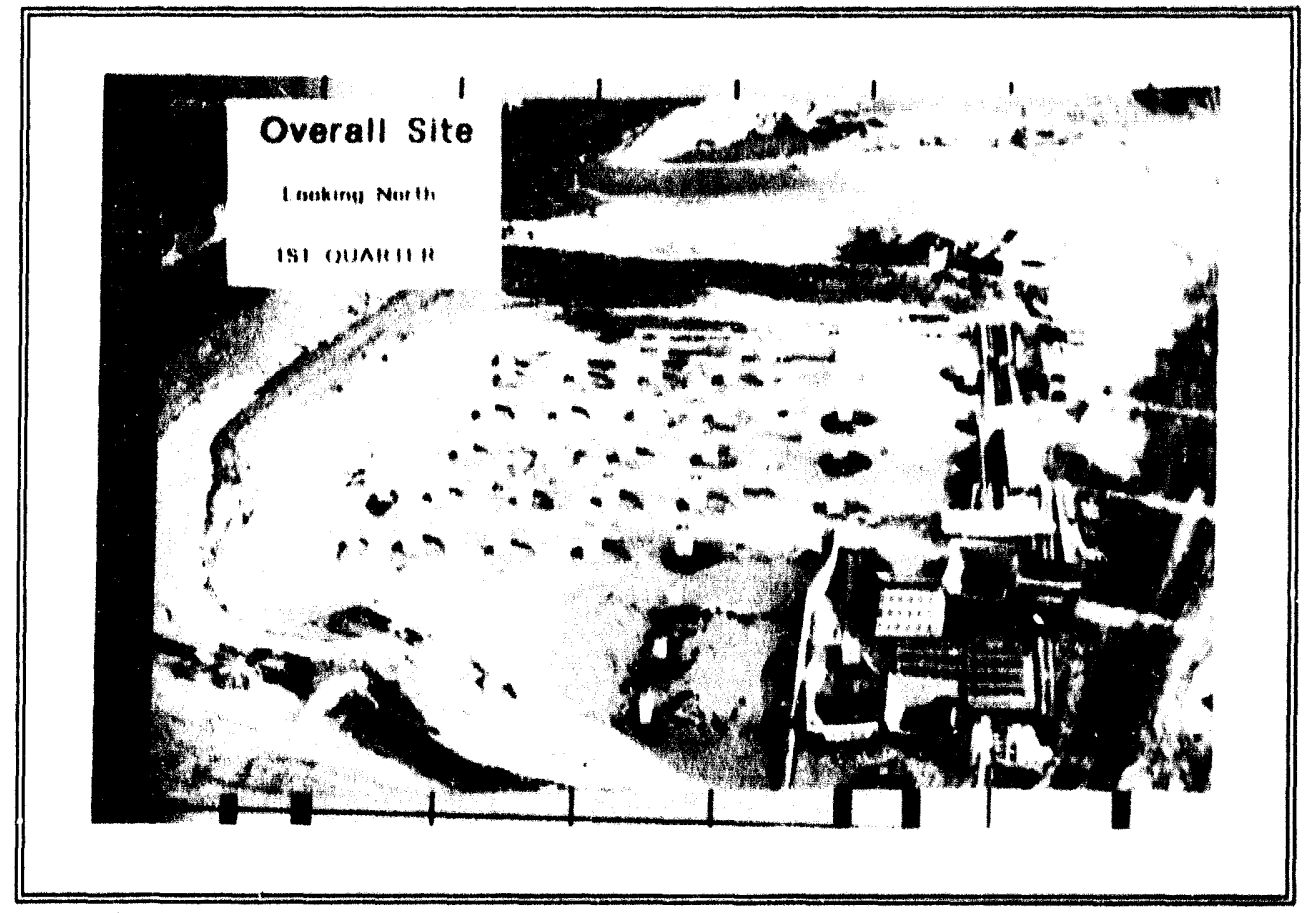

FIGURE 9: PDF Structure Foundation Looking North (January 1991).

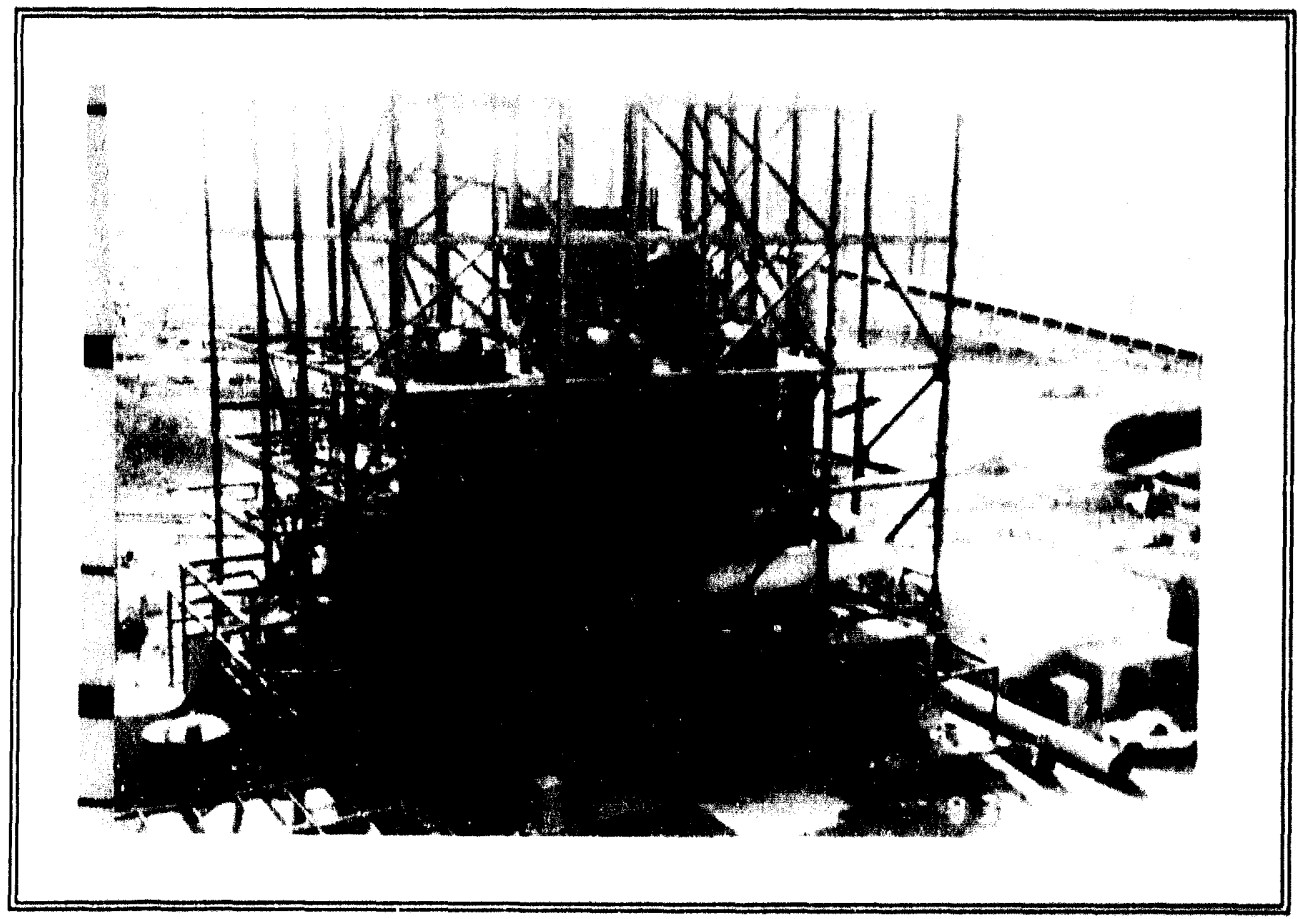

FIGURE 10: PDF Structure Looking East (Octoher 1991). 


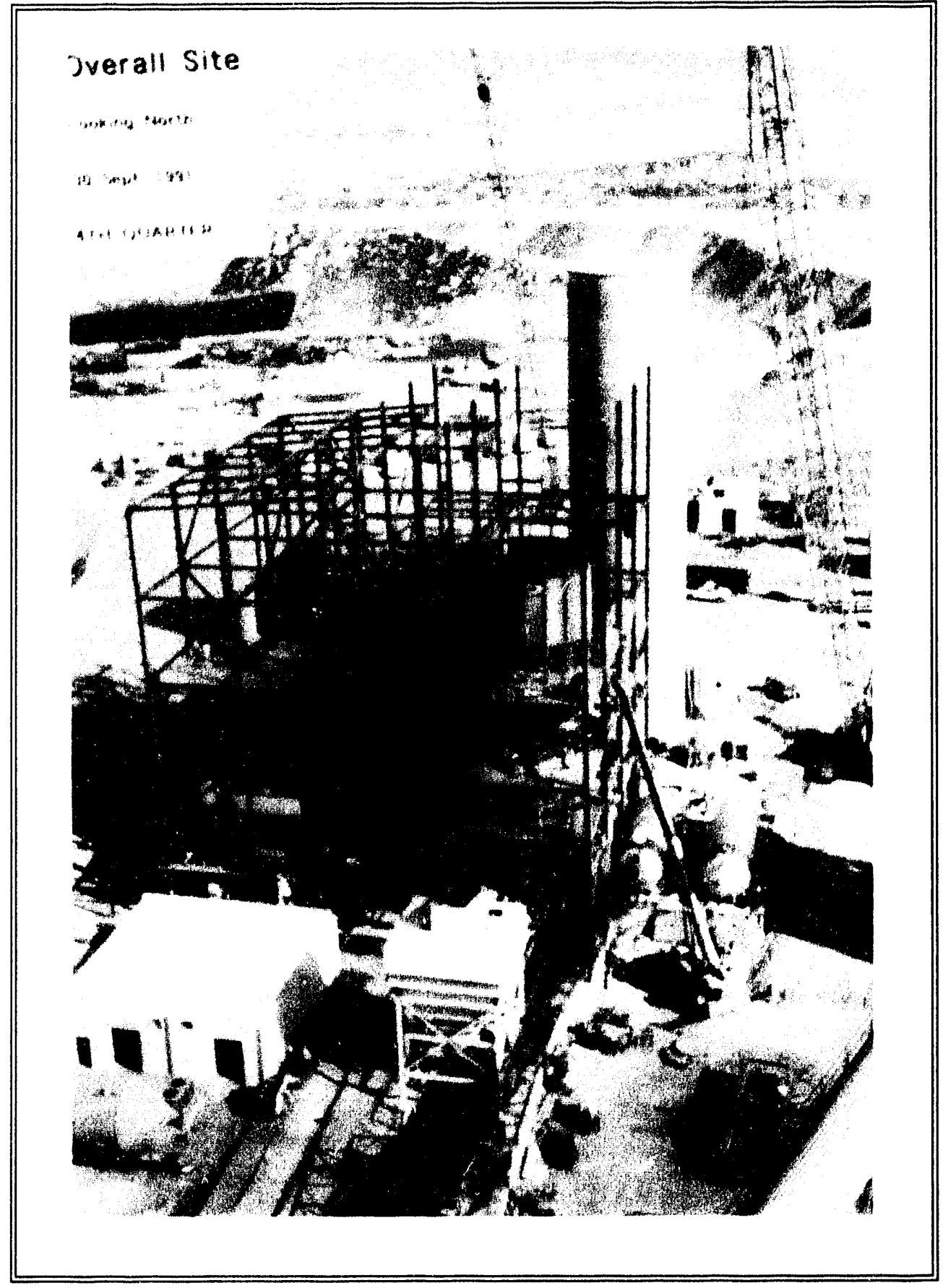

FIGURE 11: PDF Structure Looking North (September 1991). 


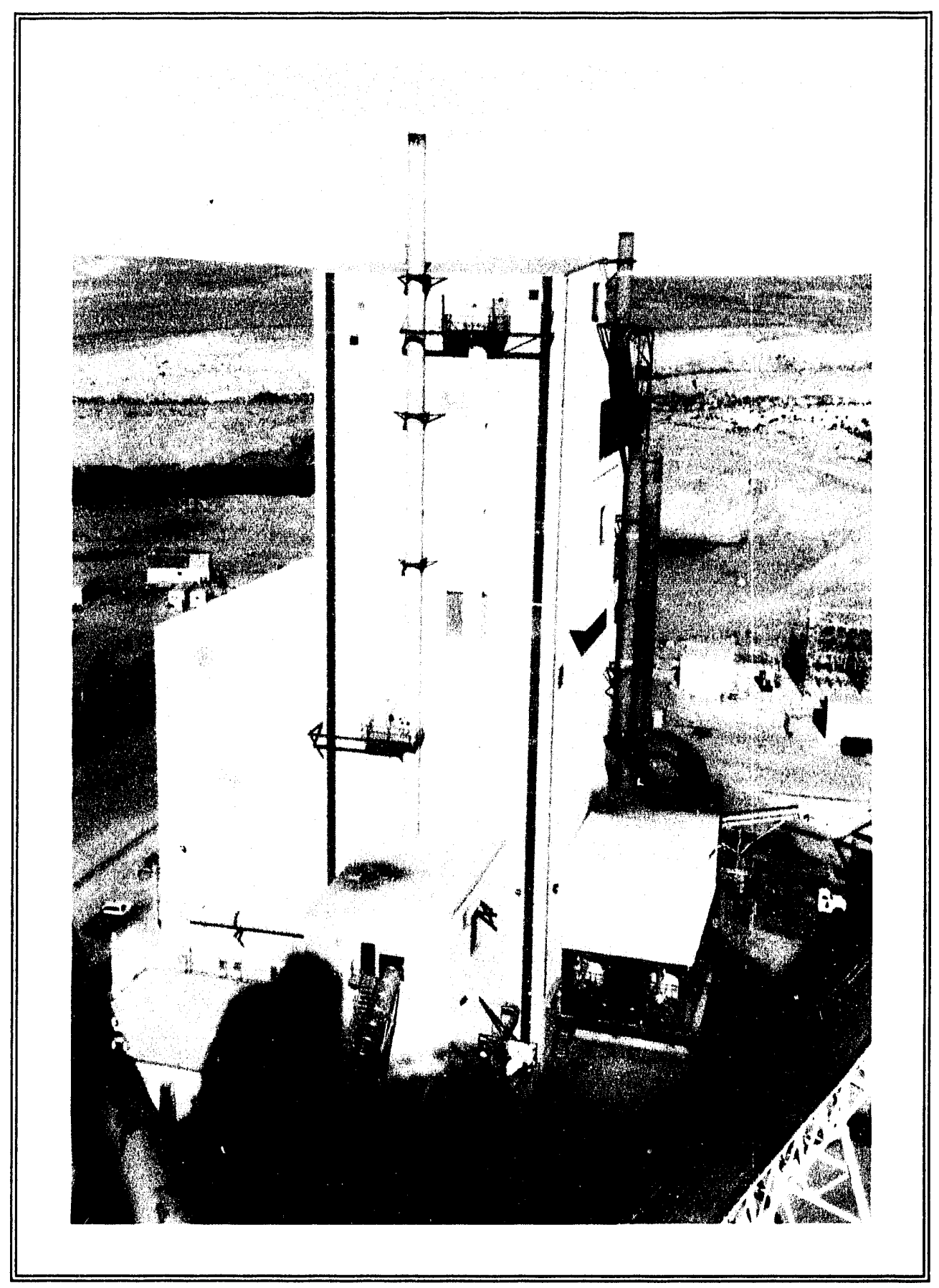

FIGURE 12: PDF Structure Looking North (September 1992). 


\section{GLOSSARY}

BACT

CDL

DOE

EMP

ENCOAL

EPA

EPC

ESP

FGD

$\mathrm{HazOp}$

$\mathrm{KCI}$

Kellogg

LFC

$\mathrm{MCC}$

MK

MSDS

MSHA

NEPA

PDF

PLC

PMN

PMP

P\&ID

QA/QC

SGI

TEK-KOL

WDEQ
Best Available Control Technology

Coal Derived Liquid

U.S. Department of Energy

Environmental Monitoring Plan

ENCOAL Corporation, a wholly-owned subsidiary of Shell Mining Company

U.S. Environmental Protection Agency

Engineering. Procurement, and Construction

Electrostatic Precipitator

Flue Gas Desulfurization

Hazards of Operation

Kellogg Constructors INC.

The M.W. Kellogg Company

Liquids From Coal

Master Control Center

SMC Mining Co. Patented Dust Suppressant

Material Satety Data Sheet

Mine Safety and Health Administration

National Environmental Policy Act

Process Derived Fuel

Programmable Logic Controller

Pre-Manufacture Notice

Project Management Plan

Piping and Instrumentation Diagram

Quality Assurance / Quality Control

SGI International

Partnership of SMC Mining Co. and SGI International for the licensing of the

LFC Technolugy

Wyoming Department of Environmental Quality

US GOVERNMENT PRINIING OFFICE 

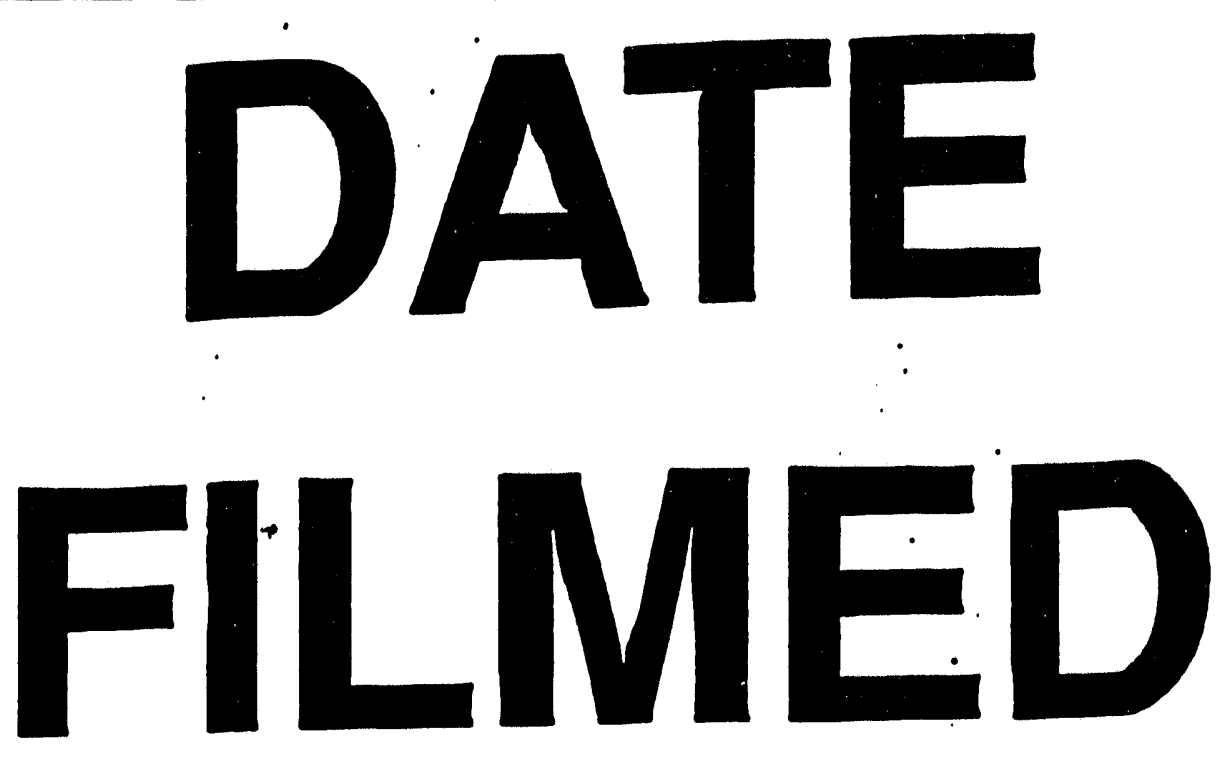

$4 / 25 / 94$
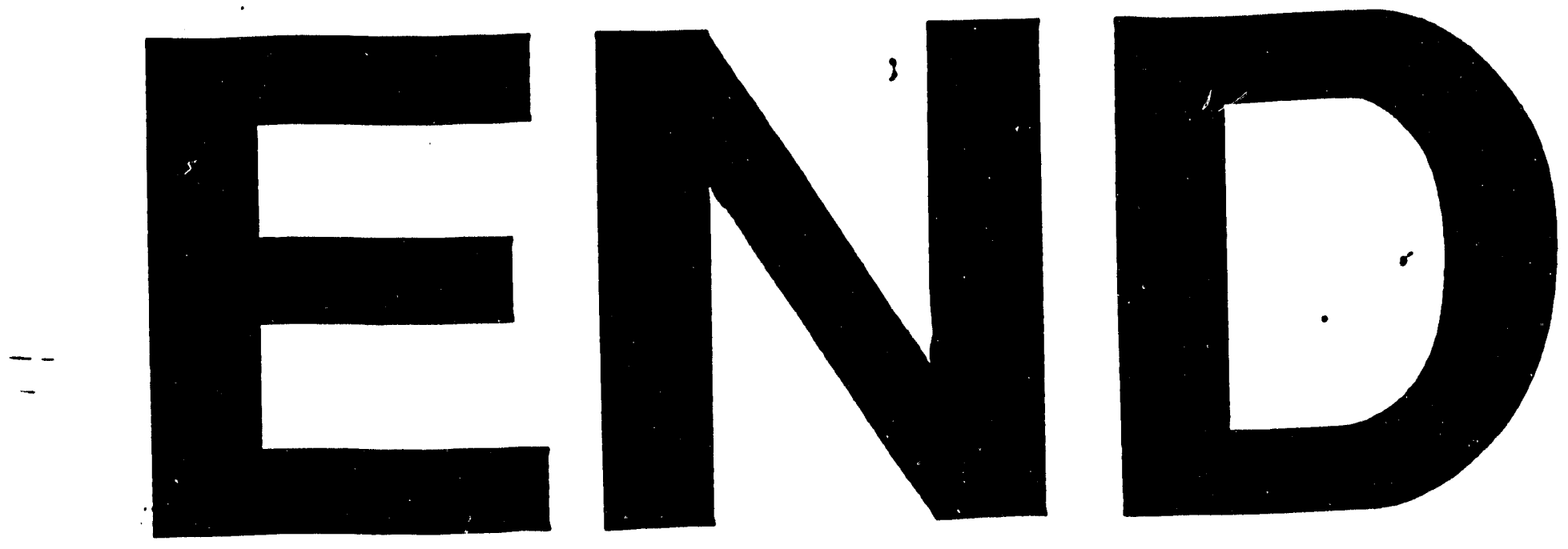
